\title{
HACIA UNA REVISIÓN DEL DERECHO A LA PROPIA IMAGEN Y DE SU CONSTRUCCIÓN EN CUANTO DERECHO FUNDAMENTAL
}

\author{
TOWARDS A REVISION OF THE RIGHT TO ONE'S \\ OWN IMAGE AND ITS CONSTRUCTION AS A \\ FUNDAMENTAL RIGHT
}

\begin{tabular}{|c|c|}
\hline \multicolumn{2}{|c|}{ ARTÍCULO INÉDITO DE INVESTIGACIÓN } \\
\hline CÓMO CITAR ESTE ARTÍCULO (CHICAGO) & 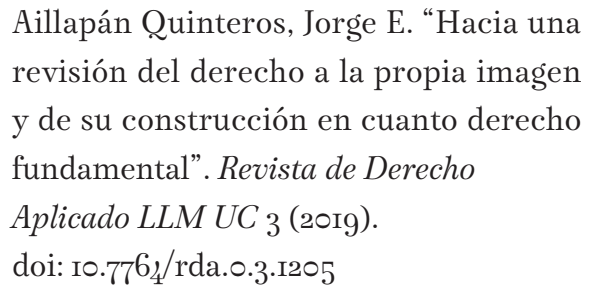 \\
\hline REVISTA DE DERECHO APLICADO LLM UC & $\begin{array}{l}\text { Número } 3 \\
\text { Julio } 20 \text { I9 } \\
\text { ISSN: } 245^{2-4} 344\end{array}$ \\
\hline & $\begin{array}{l}\text { Recepción: I8 de abril, } 20 \text { I9 } \\
\text { Aceptación: } 18 \text { de julio, 2or9 }\end{array}$ \\
\hline
\end{tabular}




\section{Resumen}

En Chile, el derecho a la imagen no cuenta con un reconocimiento constitucional expreso, de ahí que calificarlo como fundamental parezca exagerado. Entonces, zpor qué aún se le reconoce como tal? En este artículo se entregan los antecedentes histórico-jurídicos básicos para comprender por qué este tradicional derecho personalísimo llegó a ser un tópico constitucional, particularmente tras el proceso de "constitucionalización" experimentado por el Derecho privado chileno y la aparición de la acción constitucional de protección. Asimismo -y críticamente-, el autor ofrece su propia tesis para adaptar el derecho a la imagen a los tiempos actuales: la libertad para crear retratos.

Palabras clave: derecho a la imagen, retrato, derechos fundamentales, constitucionalización, recurso de protección

\section{Abstract}

It seems an exaggeration to say that the right to one's own image is a fundamental right in Chile, especially considering that it does not have an express constitutional recognition. So, why it's cataloged as fundamental right? In this text, the basic antecedents -historical and normative- are given to understand why this classic right of personality became a constitutional topic, particularly after the process of "constitutionalization" experienced by Chilean private law and the appearance of constitutional Action of Protection. Also, and critically, the author offers his own thesis to adapt the right to one's own image to the current times: the freedom to create portraits.

Keywords: right to one's own image, portrait, fundamental rights, constitutionalization, recurso de protección 


\section{Jorge Aillapán Quinteros}

Universidad Adolfo Ibáñez

Santiago, Chile

jorge.aillapan@edu.uai.cl

Universidad Adolfo lbáñez

Santiago, Chile

jorge.aillapan@edu.uai.cl
Jorge Aillapán Quinteros es licenciado en ciencias jurídicas y sociales por la Universidad de Concepción; Diplomado en Propiedad intelectual por la Universidad de Chile; y Doctor en Derecho por la Pontificia Universidad Católica de Valparaíso. Sus líneas de investigación y publicaciones muestran directa relación con dos disciplinas jurídicas: por una parte, la Propiedad intelectual y, por otra, la normativa sobre pueblos originarios. Sobre estas últimas materias, ha brindado clases en algunas universidades nacionales y actualmente dicta el curso sobre Derecho indígena en la Facultad de Derecho de la Universidad Adolfo Ibáñez, en Santiago.

Jorge Aillapán Quinteros obtained his Law degree from Universidad de Concepción. Also, he is Diploma in Intellectual Property Law of Universidad de Chile and PhD (Jur) from Pontificia Universidad Católica de Valparaíso. His lines of research and publications are in direct relationship with two legal disciplines: Intellectual Property Law and Indigenous Law. On these last subjects, he has taught at some national universities and currently is professor of Indigenous Law at the Universidad Adolfo Ibáñez, in Santiago Chile. 


\section{Introducción y marco teórico ${ }^{1}$}

Entre los desafíos básicos que plantea el estudio del derecho a la propia imagen están sus cuestiones terminológicas. Así, la inclusión del adjetivo "propia”, en su denominación, genera ya cierta discusión respecto a su utilidad y su posible vinculación con el derecho de propiedad $^{2}$. Yo tomo partido por no incluirlo y sólo llamarlo derecho a la imagen, aunque -como explico al final- mejor es designarlo como "libertad de retrato".

Sin perjuicio de lo anterior, debo comenzar por despejar otra cuestión que aparentemente es sólo terminológica, pero en verdad da cuenta de una diferencia conceptual profunda. Me refiero a la indiferenciada calificación de aquel como derecho humano, personalísimo o fundamental. Sirva de ejemplo la afirmación de Paulino Varas: «el derecho a la propia imagen forma parte de los llamados derechos de la personalidad, es decir, aquellas propiedades que son inherentes a cada persona, por lo cual el Estado y su normativa deben estar al servicio de las personas protegiendo y respetando los derechos esenciales que emanan de la naturaleza humana» ${ }^{3}$. Hay quienes plantean que los derechos "personalísimos" y los "fundamentales" son giros que apuntan a la misma institución: los derechos de la persona ${ }^{4}$. Por mi parte, en cambio, sigo la división sugerida por Aldunate Lizana para quien los personalísimos operan en un universo jurídico diferente al de los fundamentales, estando los primeros vinculados al ámbito del Derecho privado -concretamente, a los derechos subjetivos privados y su eventual tráfico-, y los segundos reservándose para la dogmática constitucional ${ }^{5}$. A mi juicio, la separación entre estas categorías es de suma utilidad para explicar la historia y actualidad del derecho a la imagen en Chile, pues desde fines del siglo XIX fue construyéndose como un derecho personalísimo y extrapatrimonial, y a su estudio estaba abocado nada más que la iusprivatística de este país ${ }^{6}$. Sólo tras el proceso de "constitucionalización" experimentado por el Derecho privado chileno, la "propietarización" de los reclamos ante las Cortes y el uso del recurso de protección, la

1 El autor agradece las críticas, comentarios y sugerencias planteadas por los árbitros al presente texto.

Cf. Ana Azurmendi, El derecho a la propia imagen: su identidad y aproximación al derecho a la información (México D.F.: Universidad Iberoamericana, I998), 3.

3 Paulino Varas Alfonso, "El respeto a todo derecho inherente a la persona, aunque no esté contemplado en el texto de la Constitución”, Revista Chilena de Derecho 20, nº 2 y 3 (I993): $3^{8} 3$.

4 José Ramón De Verda y Beamonte, "Los derechos fundamentales de la personalidad (al honor, a la intimidad y a la propia imagen) como categoría unitaria”, Revista Boliviana de Derecho 23 (20I7): $59-63$.

5 Eduardo Aldunate Lizana, Derechos fundamentales (Santiago: Legal Publishing, 2008), 57.

6 Fernando Fueyo Laneri, Instituciones de Derecho Civil moderno (Santiago: Editorial Jurídica de Chile, r990), 2I-26. 
jurisprudencia chilena vino a reconocerlo como un nuevo derecho fundamental, aunque implícito toda vez que hasta hoy no cuenta con un reconocimiento en la Constitución de 1980. Precisamente, el texto que ahora ofrezco constata lo anterior: el derecho a la imagen es un derecho fundamental creado por la Corte Suprema y las Cortes de Apelaciones a través de la jurisprudencia emanada, durante las últimas cuatro décadas, de recursos de protección que versaban precisamente sobre usos y abusos de imágenes de personas.

Huelga mencionar que la información que ahora entrego fue recopilada en el contexto de la investigación para mi tesis doctoral en Derecho, la cual versó precisamente sobre el derecho a la imagen en Chile ${ }^{7}$ y cuyo marco teórico-conceptual describo sucintamente a continuación para dejar en claro qué entiendo yo por tal instituto. Siguiendo el esquema tradicional -y al no existir un texto positivo ${ }^{8}$ - las fuentes nacionales que consideré para abordar la cuestión fue la jurisprudencia de los recursos de protección y la literatura chilena que se ha ocupado en específico de este tema. Al analizarlas, prontamente noté dos cuestiones: en primer lugar, que no todas las imágenes sobre personas naturales generaban reproches jurídicos, sino sólo aquellas que permitían la identificación de éstas, y así se ha sostenido, por ejemplo: «que en un caso como el que se analiza, en que se recurre de protección por estimarse que se ha afectado un aspecto tan singular del derecho de propiedad, cual es el derecho a la imagen, ha de requerirse necesariamente como exigencia fáctica básica que la figura utilizada sea reconocible, es decir, permita su identificación indubitada, situación que no se verifica en la fotografía publicada» ${ }^{9}$. La segunda cuestión que noté fue que el contexto de la captura o creación de la imagen se imponía al consentimiento de la persona. En efecto -y en casi la totalidad de las situaciones analizadas- si la imagen se obtenía en contextos "públicos" la dogmática chilena estimaba que no había vulneración a tal derecho, incluso si el retrato se obtenía contra el consentimiento del efigiado. Al ser accesorio -además de la propiedad- del derecho a la vida privada y la honra de la persona, el amparo sólo operaba si, mediante una imagen, se afectaba la buena reputación o privacidad del efigiado. Mi actitud frente a estas situaciones fue, por una parte, clasificar las imágenes de personas naturales en dos grupos: aquellas que identificaban inmediatamente a éstas -o aportaban datos suficientes para $\mathrm{ello}^{10}$ - versus las que no ${ }^{11}$. Respecto a la segunda cuestión -contexto de la captura-, me propuse relevar el consen-

7 "El derecho fundamental a la imagen en el ordenamiento jurídico chileno" (Doctorado en Derecho de la Pontificia Universidad Católica de Valparaíso, 20I8).

8 Salvo el Código del Trabajo que reconoce y regula "el uso y explotación comercial de la imagen",

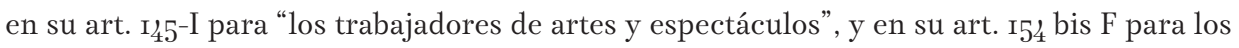
"deportistas profesionales y de los trabajadores que desempeñan actividades conexas".

9 SCA de Santiago 5595-I999, 26 de enero de 2000.

10 Que designé como "retratos".

11 Que designé simplemente como "imágenes" o "imágenes de personas". 
timiento de la persona frente a los retratos, es decir, mediante el estudio e interpretación sistemática de la mayor parte de la normativa infraconstitucional chilena que regula la creación de este tipo de imágenes fijé el rol que tiene la voluntad o consentimiento de la persona frente a la captación o creación de un retrato. En este cometido, logré recopilar un sinnúmero de datos positivos que mandan, prohíben y hasta permiten crear imágenes de personas. Entre los que obligan a retratarse está la normativa relativa a la fotografía de cédula de identidad ${ }^{12}$ o del prontuario pena ${ }^{13}$, por ejemplo. Entre la que prohíbe están la ley sobre Propiedad Industrial ${ }^{14} \mathrm{o}$ la ley "de Prensa" ${ }^{15}$. En cuanto a la normativa que tolera o permite captar fotografías podemos mencionar al Código Procesal Penal ${ }^{16}$, aunque una interpretación sistemática me permitió constatar, además, que el legislador chileno viene regulando la creación y tráfico de retratos, al menos, desde la promulgación del Código Civil por medio de la institución del arriendo de servicios inmateriales y de la normativa sobre Propiedad intelectual de los retratos ${ }^{17}$. Derivadas de esta última constatación, obtuve tres conclusiones. Primero, obviamente que el legislador chileno permite la creación de retratos. Segundo, que no sólo se tolera la creación, sino también el tráfico de retratos y de derechos de imagen. En efecto, si atendemos al art. 1466 del Código Civil cuando dice que «[h]ay asimismo objeto ilícito en la venta de láminas, pinturas y estatuas obscenas, y de impresos condenados como abusivos de la libertad de prensa», podemos concluir

12 Resolución $N^{\circ}$ 86r exenta, del Ministerio de Justicia y del Servicio de Registro Civil e Identificación, publicada en el Diario Oficial el 2 de septiembre de 2013.

13 Art. I del D.S. N 64, de r960, por el cual el Ministerio de Justicia "Reglamenta la eliminación de prontuarios penales, de anotaciones y el otorgamiento de certificados de antecedentes".

14 El art. 20 letra c) de la Ley $\mathrm{N}^{\circ}$ I9.039 prohíbe registrar como marca comercial "el retrato de una persona natural cualquiera, salvo consentimiento dado por ella o por sus herederos, si hubiera fallecido".

15 El inc. I del art. 33 de la Ley $\mathrm{N}^{\circ}$ I9.733 “prohíbe la divulgación, por cualquier medio de comunicación social, de la identidad de menores de edad que sean autores, cómplices, encubridores o testigos de delitos, o de cualquier otro antecedente que conduzca a ella”. O, también, la Ley $\mathrm{N}^{\circ}$ 2I.057, publicada el 20 de enero de 20I8, y que "regula entrevistas grabadas en video y otras medidas de resguardo a menores de edad, víctimas de delitos sexuales".

16 Al efecto, se señala en la letra c) del art. 289 -titulado "publicidad de la audiencia del juicio oral"- que en la audiencia del juicio oral "los medios de comunicación social podrán fotografiar, filmar o transmitir alguna parte de la audiencia que el tribunal determinare, salvo que las partes se opusieren a ello".

17 Por ejemplo, nuestra literatura da cuenta que en $\mathrm{I} 887$ la C.A. de Iquique resolvía ya un conflicto entre un fotógrafo y efigiado precisamente atendiendo al Código Civil, aunque calificando -en dicha oportunidad- el contrato de confección de retrato fotográfico como compraventa, cf. Alessandri, Arturo y Manuel Somarriva, Tratado de Derecho Civil, partes preliminar y general, Tomo I (Santiago: Editorial Jurídica de Chile, 20I0), 493 . 
contrario sensu que en Chile se permite la venta de retratos que no sean obscenos y de impresos no condenados como abusivos de la libertad de prensa. Luego, si se tolera la enajenación o venta a maiori ad minus debemos entender que primeramente se autoriza la creación de imágenes no destinadas al comercio. Por último, logré constatar que efectivamente derecho a la imagen y Propiedad intelectual son dos caras del mismo fenómeno ${ }^{18}$ : el retrato de personas.

La regulación jurídica del retrato de personas existe desde antaño ${ }^{19}$, mas sólo en la última década -con ocasión de la universalización de las tecnologías que permiten crear, reproducir y comunicar públicamente imágenes- es que dicho fenómeno ha cobrado nuevos bríos, particularmente con el desafío de justificar la televigilancia, los autorretratos o selfies y, más aún, el millonario mercado de la cesión de derechos de imagen ${ }^{20}$. A mi juicio, el derecho a la imagen no es más que la libertad reconocida a toda persona natural para crear retratos y eventualmente traficarlos. Así de simple. Si de sus virtualidades y posibilidades se trata, éstas van desde la autodeterminación para no crear retratos y/o impedir que terceros los generen, pasando por la generación de autorretratos, hasta las convenciones que el ordenamiento jurídico regula a fin de que un tercero capte retratos nuestros, gratuitamente o por medio de un pago en dinero. Insisto que no se trata de una imagen cualquiera sino específicamente de un "retrato", es decir, la representación de una persona natural mediante un signo visual que la identifique o aporte datos suficientes para identificarla, con absoluta prescindencia del formato que adopte dicha imagen, pudiendo ser bidimensional -i.g. pinturas-, tridimensional -i.g. esculturas-, analógica -i.g. caricaturas-, digital -i.g. memes-, fijas -i.g. fotografías-, en movimiento -i.g. videogramas, televisión-, etcétera. A lo largo del texto iré mencionando otras características, mas en esta oportunidad no busco explicar el porqué de la "fundamentalidad material" ${ }^{21}$ del derecho a la imagen, sino tan sólo que el lector conozca cómo y cuándo este instituto llegó a ser objeto de consideración por el constitucionalismo chileno, pese a que ni siquiera hoy esté positivado en la Carta de 1980.

18 Santos Cifuentes, Derechos personalísimos, $2^{\mathrm{a}}$ ed. actualizada y ampliada (Buenos Aires: Editorial Astrea, I995), $5^{22}$.

19 Hay quienes, incluso, la vinculan hasta el Derecho romano, como en Ernesto Perla Velaochaga, "El derecho a la propia imagen”, Derecho PUCP I (I944): 35.

20 Particularmente respecto a las "superestrellas" del fútbol y otros deportes masivos.

21 Robert Alexy, Teoría de los derechos fundamentales, Traducido por Carlos Bernal Pulido, $2^{\mathrm{a}}$ reimpresión de la $2^{\mathrm{a}}$ ed. (Madrid: Centro de Estudios Constitucionales, 20I2), $4_{4}^{6} \mathrm{I}_{4} 63$. 


\section{De la incardinación del derecho a la imagen en el debate constitucional chileno}

\section{El derecho a la imagen como libertad innominada de Derecho privado}

En Chile, el estudio del derecho a la imagen surgió al amparo de la iusprivatística en cuanto personalísimo y extrapatrimonial. En dicho contexto, nuestra dogmática se ha desvelado ante la supuesta imposibilidad de deslindar al sujeto/objeto del derecho y, por ende, considerarlo subjetivo ${ }^{22}$. Pero, en verdad, ha sido la posibilidad de comercio, patrimonialidad y traficabilidad de los derechos personalísimos -en general- la verdadera razón de dicho desvelo ${ }^{23}$. En efecto, una arraigada tradición, en nuestro país, le ha negado históricamente dichas posibilidades al derecho a la imagen, no obstante calificarlo como subjetivo-privado. De esta manera, su cualidad principal -en cuanto personalísimo- consistiría en que todos los demás individuos de la sociedad han de hacer nada para que el titular no vea amenazado o conculcado derecho ${ }^{24}$. Es decir, sólo daría origen a una obligación de no hacer ${ }^{25}$, jamás de dar ${ }^{26}$. Sin embargo, dicha doctrina en nada se condice con la realidad, de ahí la necesidad de considerar al derecho a la imagen como una libertad fundamental que implica la autodeterminación personal para impedir retratos no consentidos, pero también para autorretratarse y operar en el ámbito del Derecho privado obligándose a hacer ${ }^{27}$, no hacer ${ }^{28}$ e, incluso, a dar ${ }^{29}$.

Cf. Alberto Lyon Palma, Personas naturales, $3^{\mathrm{a}}$ ed. ampliada (Santiago: Ediciones Universidad Católica de Chile, 2007), 76 y ss.

23 Cf. Jorge Aillapán Quinteros, "Derecho a la propia imagen: ¿derecho personalísimo?, ¿derecho fundamental? Precisiones terminológicas para el ordenamiento jurídico chileno", Revista Chilena de Derecho $43, \mathrm{n}^{\circ} 2$ (2016): $45^{2-454}$.

24 Cf. Alejandro Guzmán Brito, El Derecho Privado Constitucional de Chile (Valparaíso: Ediciones Universitarias de Valparaíso, 200I), 86.

25 No retratar, salvo autorización del titular.

26 Según Guzmán Brito, hay algunos derechos personalísimos que podrían generar una obligación de hacer-como, por ejemplo, los denominados "derechos sociales" respecto del Estado- más nunca podrán generar obligaciones de dar, cf. Alejandro Guzmán Brito, Las cosas incorporales en la doctrina y en el Derecho positivo, $2^{\mathrm{a}}$ ed. actualizada (Santiago: Editorial Jurídica de Chile, 2006), 85-86.

27 Por ejemplo, si el titular de dicha libertad trabaja como "rostro", modelo o influencer y conviene con un tercero -a través de un contrato publicitario o de modelaje- a dejarse retratar en beneficio de este último.

28 Por ejemplo, si el titular de dicha libertad -que trabaja como "rostro", modelo o influencer-así lo conviene con un tercero a través de un contrato publicitario o de modelaje en el cual se establece una cláusula de exclusividad para retratarse sólo en beneficio de este tercero.

29 En el contexto de la libertad de retrato, las personas pueden obligarse a dar, por ejemplo, cuando el retratista cobra un precio en dinero por crear una fotografía, video o pintura del titular de dicha libertad. 
Para el medio chileno se ha planteado que la Constitución de 1980 hace de "derecho" y "libertad" términos convertibles y aunque puedan diferenciarse, por su contenido, entre "derechos de libertad" frente a los "derechos a prestaciones", lo cierto es que en su raíz todos los derechos son libertades y todas las libertades son derechos ${ }^{30}$. Cierta o no, esta afirmación no nos ayuda a dar solución al tráfico de los derechos de imagen y, en general, a la «situación particular en que se encuentra una persona o conjunto de personas en relación al Derecho objetivo» ${ }^{31}$. El español Rogel Vide -siguiendo a Carbonnier- avanza un poco más al señalar que los derechos de la personalidad constituyen prerrogativas suficientemente precisas en relación con su objeto, desde que las libertades civiles implican más bien la posibilidad reconocida a las personas de hacer cuanto les plazca, de poder actuar según su libre albedrío y, por lo tanto, no alcanzan a constituir un derecho subjetivo, en términos técnicos ${ }^{32}$. Mejor aun, eso sí, resulta apelar al clásico modelo expuesto por Hohfeld $^{33}$, quien planteó una clara diferencia entre los derechos subjetivos ${ }^{34}$ y las libertades o privilegios ${ }^{35}$, modelo que nos permite avanzar hacia la justificación del derecho a la imagen como una libertad operativa en el ámbito del Derecho privado.

Como señalara este jurista estadounidense, el sinónimo más próximo de "privilegio" -jurídico- parece ser el de "libertad" -jurídica-, desde que reafirma la existencia de una relación jurídica más allá de una mera libertad física o ausencia de restricción física ${ }^{36}$. Junto con ello, se encarga de precisar que el "correlativo" ${ }^{37}$ de una libertad es un "no derecho" ${ }^{38}$, es decir, la ausencia de un derecho subjetivo de algún tercero para actuar dicha libertad, máxime si se asume que éstas consisten precisamente en un atributo de

Cf. Guzmán Brito, El Derecho..., I58-I59.

31 Carlos Nino, Introducción al análisis del Derecho, $\mathrm{1}^{\mathrm{a}}{ }^{\mathrm{a}}$ reimpresión de la $2^{\mathrm{a}}$ edición ampliada y revisada (Buenos Aires: Editorial Astrea), 195 .

32 Cf. Carlos Rogel Vide, "Origen y actualidad de los derechos de la personalidad", IUS: Revista del Instituto de Ciencias Jurídicas de Puebla A.C. 20 (2007): 264.

33 Wesley Newcomb Hohfeld, Conceptos jurídicos fundamentales, 5 a reimpresión de la primera edición, traducido por Genaro Carrió (México D.F.: Distribuciones Fontamara S.A., 2004).

34 En su concepción, un derecho subjetivo -right, claim- es una pretensión subjetiva reconocida o tutelada por el orden jurídico, Hohfeld, Conceptos..., 53.

35 Privileges.

36 Ya al inicio de su ensayo, Hohfeld ponía acento precisamente en la diferencia entre las relaciones jurídicas y los hechos físicos o psíquicos que las hacen surgir, Hohfeld, Conceptos..., 33 y 67 y ss.

37 Jural correlative.

38 Un no-right. En cambio, el "opuesto" -jural opposite- de una libertad es un "deber" -duty-, Hohfeld, Conceptos..., 49 . 
una acción o conducta. Así, y parafraseando los ejemplos entregados por dicho autor, podemos decir que si $A$ tuviera un derecho subjetivo cuyo contenido impide a $B$ crearle un retrato, la situación correlativa ${ }^{39}$ es que $B$ tiene el "deber" ${ }^{{ }_{40} 0}$ de no crear algún retrato de $A^{41}$. Revisando la literatura, da la impresión que a esta figura parece referirse la dogmática chilena cuando ofrece explicar las relaciones jurídicas aplicadas al campo de los derechos personalísimos. En cambio -y continuando con el parafraseo a los ejemplos de Hohfeld-, si $A$ tuviera la libertad de crear retratos, la situación correlativa y equivalente es que tanto $B$ como el resto de la sociedad tienen el "no-derecho" de actuar dicha libertad de $A$; en otras palabras, que no pueden impedir ni forzar jurídicamente a $A$ para crear retratos $^{42}$. Ahora bien, al ser la libertad un atributo de acción o conducta, que puede ser actuado, es que podemos decir que ante el Derecho privado chileno el derecho a la imagen no es uno subjetivo personalísimo, sino que es una libertad-innominada- en cuya virtud toda persona puede crear o no crear retratos. Así, si $B$ contratara con $A$, obligándose a crear un retrato, a la libertad de $B$ se vendría a sumar el deber para con $A^{43}$. En ese caso, libertad y deber coincidirían en un aspecto y con el mismo contenido: crear un retrato en favor de $A^{44}$. Lo útil del esquema Hohfeldiano es que permite explicar por qué $A$ puede generar derechos subjetivos privados en favor de $B$, pero -y, al mismo tiempo- conservar intacto su privilegio o libertad respecto de todo el resto de la sociedad para crear o no retratos ${ }^{45}$, es decir, su autodeterminación en ese sentido. Asimismo, nos sirve como punto de partida para comenzar a reafirmar la negada virtualidad que presenta el derecho a la imagen en Chile ya que este instituto, operando en el ámbito del Derecho privado, no ha de entenderse sólo como un deber de abstención para retratar a las personas, sino que resulta ser mucho más virtuoso.

Se ha dicho, para nuestro medio, que el proceso de "constitucionalización" vino a reformar el Derecho privado chileno abriendo paso al desarrollo legislativo de clásicos derechos, abrogando figuras vigentes y, también, favoreciendo el reconocimiento de derechos im-

39 Y equivalente.

40 En el esquema de Hohfeld, el correlativo de un derecho es un deber. En cambio, el opuesto es un no-derecho, cf. Hohfeld, Conceptos..., 49.

$41 \mathrm{Su}$ "opuesto" sería un "no-derecho".

42 Al mismo tiempo, dicha libertad implica la negación y/o anulación de "lo opuesto" que, en este caso, consiste en que $B$-y resto de la sociedad- no tienen deber alguno respecto de $A$. En principio, ese "no-derecho" sólo habilitaría para nada hacer respecto al privilegio o libertad de A, cf. Hohfeld, Conceptos..., 53-54.

43 Quien tendría el correlativo derecho subjetivo para exigirle a $B$ crear un retrato de él.

44 Cf. Hohfeld, Conceptos..., 54.

45 Salvo, claro, que haya pactado exclusividad $\operatorname{con} B$. 
plícitos mediante la interpretación sistemática y coordinada de las diversas normas y principios del Derecho privado, aunque ahora a la luz de la dogmática constitucional ${ }^{46}$. Sobre esto último, el reconocimiento constitucional de ciertos derechos implicaría que preexistían a la Constitución, de ahí que la novedad del fenómeno no radicaría tanto en su creación, sino sólo en su cambio de rango ${ }^{47}$. Tratándose del Derecho privado, como por definición consiste en la regulación de la libre adquisición y conservación de las cosas, el libre cambio recíproco de éstas y de servicios entre los individuos, la idea de libertad ocupa un lugar central en él, de la misma manera que ocurre respecto a los derechos o libertades garantizados en la Constitución y que precisamente le dan sostén. En efecto, el Derecho privado supone una serie de libertades que están garantizadas expresamente en la Constitución y que por ello han de considerarse "nominadas" ${ }^{28}$ como ocurre, por ejemplo, con la libertad de trabajo (art. $19 \mathrm{~N}^{\circ} 16 \mathrm{CPR}$ ) o la libertad para adquirir bienes (art. 19 $\mathrm{N}^{0} 23 \mathrm{CPR}$ ). Hay otras, en cambio, que estando asumidas por las leyes del Derecho privado no están constitucionalmente reconocidas y, en apariencia, no gozarían de la supremacía respectiva, pero en verdad sí, pues pueden ser justificadas en la declaración general de que "las personas nacen libres" (art. 1 inc. I CPR), sólo que por no estar expresamente designadas en nuestra Constitución habrá que anotarlas como "innominadas" ${ }^{29}$. En efecto, examinando la consistencia interna del Derecho privado chileno se puede concluir que está fundado en varias otras libertades -distintas a la que tradicionalmente menciona la Constitución- como ocurre, por ejemplo, con la "libertad de investigación científica y tecnológica" ${ }^{50}$, la "libertad para crear y difundir las artes" ${ }^{51}$, la "libertad de pesca" ${ }^{52}$ o la "libertad de matrimonio" ${ }^{53}$. Mi propuesta es que, dentro de este listado, habría que incluir

46 Cf. Ramón Domínguez Águila, "Aspectos de la constitucionalización del Derecho civil chileno", Revista Derecho y Jurisprudencia y Gaceta de los Tribunales 93, nº 3 (I996): I3.

47 Cf. Guzmán Brito, El Derecho..., $3^{6}$ y $5^{\text {I. }}$

48 Alejandro Guzmán denomina libertades de Derecho privado "nominadas" a aquellas que "la Constitución las describe expresa y directamente, o porque resultan contenidas en la descripción de una específica libertad, no obstante exceder ésta al Derecho privado”, Guzmán Brito, El Derecho..., 223. Guzmán Brito, El Derecho..., ı67.

50 Cf. Guzmán Brito, El Derecho..., 28r. En lenguaje de Carl Schmitt, esta libertad se correspondería a una "garantía institucional", cf. Carl Schmitt. Teoría de la Constitución, $2^{\text {a }}$ reimpresión, traducido por Francisco Ayala (Salamanca: Alianza Editorial, I996), I77.

51 Tomás Vial Solar, "El derecho a la libertad de creación artística en la Constitución”, Libertad de expresión en Chile, ed. por Felipe González (Santiago: Facultad de Derecho, Universidad Diego Portales): $243^{-286 .}$

52 Esto es, de “adquirir por ocupación los peces del mar”, Guzmán Brito, El Derecho..., $5^{8 .}$

53 Javier Barrientos Grandón, “De la inexistencia del matrimonio en el Derecho chileno”, Revista Chilena de Derecho I9, $\mathrm{n}^{\circ} 2$ (2006): 60. 
a la "libertad de retrato" toda vez que está asumida y regulada, desde mediados del siglo XIX, en las diferentes normas y principios recogidos en el Código Civil, en la legislación sobre propiedad intelectual, en el Código del Trabajo, en la legislación penal y demás normativa pertinente referida a la creación, tráfico, uso y abuso de retratos, regulación toda que -sistematizada- permite identificar y reconfigurar el contenido protectivo y las afectaciones a que están sujetas las posibilidades de ejercicio del derecho a la imagen en Chile.

\section{La constitucionalización del Derecho privado chileno}

Santos Cifuentes ${ }^{54}$ ha ordenado, en siete grupos, las tesis desarrolladas en el ámbito comparado para explicar la naturaleza jurídica de la relación que existe entre una persona y su imagen. De esta manera -y además de aquella doctrina que niega la existencia de tal derecho- es posible identificar una teoría "materialista", para la cual el objeto a proteger sería el cuerpo humano. En contraposición a ésta, se forjó la teoría denominada "emanación de la personalidad”, en cuya virtud se reconoce nuestra capacidad de autodeterminación para retratarnos y, también, una tesis que plantea que lo protegido -por el derecho a la imagen- es la "identidad personal". Por último, comenta este autor, se han desarrollado aquellas teorías que califican la relación entre una persona y su imagen como un derecho a la honra, como un derecho de propiedad -sobre bienes corporales e incorporales- y, por último también, como una manifestación del derecho a la vida privada. En Chile, son estas últimas tres tesis las que en mayor o menor medida se utilizan, en la actualidad, para calificar jurídicamente la relación persona-imagen y, de paso, justificar su amparo constitucional en cuanto derecho fundamental implícito, aunque su identificación con el derecho a la vida privada sea el que continúe primando, tal como lo ha reafirmado la Corte Suprema recientemente: «que en lo tocante al resguardo constitucional del derecho a la propia imagen, a que precisamente tiende la acción propuesta en autos, es cierto que el artículo 20 de la Carta Fundamental no lo enumera determinadamente entre las garantías susceptibles de ampararse por ese arbitrio cautelar, pero tanto la doctrina como la jurisprudencia coinciden en que su protección deviene procedente y encuadra en el artículo $19 \mathrm{~N}^{\circ} 4$ de la Constitución, por encontrarse implícitamente comprendida en el atributo de privacidad de la persona, que esa norma se encarga de tutelar (C.S., Rol 9970-2015) $\gg^{55}$. Precisamente, en Chile, el tránsito que tuvo la privacidad desde la iusprivatística a la Carta de 1980 (art. 19 N 4), en el contexto de la "constitucionalización del Derecho privado", favoreció -al mismo tiempo- el ascenso del derecho a la imagen al plano constitucional. Por ello que su contenido protectivo rinda tributo y continúe identificándose con aquella prerrogativa $^{56}$, soslayando los enfoques y antecedentes provenientes desde fuera del Dere-

54

55

56

\footnotetext{
Cifuentes, Derechos..., 502 y ss.

SCSJ 22056-20I8, del 2 de enero de 2019.

Actualmente, también, en sintonía con la "autodeterminación informativa” y la consideración del derecho a la imagen como un "dato personal”. A este respecto, véase la historia de la Ley N ${ }^{\circ}$ 2r.og6 (20I8) que modificó el numeral 4 del art. Ig de la Constitución, incluyendo la protección a los datos personales.
} 
cho civil y con los cuales resulta posible reconstruir una estructura que abone su carácter de derecho fundamental, esta vez, de acuerdo a una correcta dogmática constitucional.

En general, el fenómeno de la constitucionalización se ha ido definiendo a partir de la nueva dinámica propuesta para la Constitución en su relación con el resto del ordenamiento jurídico y, en concreto, por ciertos hitos como son la incorporación en los códigos políticos respectivos de un catálogo más exhaustivo de derechos, por la aparición o restablecimiento de los tribunales constitucionales, por la introducción de acciones y recursos cautelares de los derechos fundamentales, y hasta por el énfasis en una jurisdicción preventiva más que punitiva ${ }^{57}$. Aunque es la cuestión conocida como "efecto horizontal" de los derechos fundamentales -o Drittwirkung- lo que más caracteriza o define a este fenómeno, es decir, que en Chile la Constitución puede aplicarse a las relaciones entre particulares -ya de manera directa o indirecta ${ }^{58}$ - e incluso permitiendo descubrir "fuentes" de donde emanen nuevos derechos fundamentales "implícitos", tal como ocurre con el derecho a la imagen y su forzada -y errónea- inclusión en los numerales 4 y 24 del art. 19 de la Constitución.

En este contexto, el reconocimiento que la dogmática chilena hizo a un implícito derecho fundamental a la imagen dice relación, por una parte, con la renovación de diversas figuras de Derecho privado y, al mismo tiempo, con el uso técnico que se hizo de la Constitución de 1980 para crear nuevos derechos fundamentales y amparar aquellos institutos mediante una herramienta jurídica específica: el recurso de protección. Este último sincretismo estaba presente ya en la reflexión que realizara, en 1996, José Luis Cea quien, junto a la constitucionalización, abordaba la "civilización del Derecho", esto es, «[1]a privatización del ordenamiento jurídico por el empleo generalizado, en los ámbitos gubernativos, de instituciones y procedimientos típicos del Derecho privado, debido a su mayor eficiencia, menores costos y métodos de fiscalización más eficaces (...) se asiste a la privatización de lo público, como sucede con las desregulaciones, el repliegue del Estado empresario, el aumento de los servicios públicos concedidos, o el auge que ha tenido el respeto a la intimidad de la vida personal y familiar» ${ }^{59}$. En un sentido similar, Corral Talciani diría después que constitucionalización del Derecho civil implica que las normas constitucionales han tenido incidencia en la conformación del sistema de Derecho privado, y no sólo respecto a materias patrimoniales -contratos, derechos reales, etc.- sino que también en

57 Cf. José Luis Cea Egaña, “La constitucionalización del Derecho”, Revista de Derecho Público 59 (I996): ı2. También se atribuye a este fenómeno la universalización de los derechos, al extenderlos igualitariamente a todos los seres humanos, cf. Guzmán Brito, El Derecho..., $5^{2}$.

Cf. Hernán Corral Talciani, "Algunas reflexiones sobre la Constitucionalización del Derecho privado”, Derecho Mayor 3 (2004): 9; Eduardo Aldunate Lizana, "El efecto de irradiación de los derechos fundamentales”, La constitucionalización del Derecho chileno, coord. Juan Carlos Ferrada Bórquez (Santiago: Editorial Jurídica de Chile-Universidad Austral de Chile, 2003), I3-I4.

Cea Egaña, "La constitucionalización del Derecho", 21. 
materias extrapatrimoniales mediante la reafirmación de la dignidad esencial, como valor rector y fundamento de la libertad e igualdad de todos los seres humanos, de los derechos esenciales que emanan de su naturaleza -y que son anteriores al Estado (art. 1 CPR)- y, asimismo, mediante «el respeto a derechos de la personalidad como el derecho a la honra, la intimidad y la imagen (art. $\left.19 \mathrm{~N}^{0} 4\right){ }^{60}$.

\section{El recurso de protección como garantía procesal del derecho fundamental a la imagen}

A propósito de la constitucionalización del Derecho privado chileno, el cambio se evidenció -entre otros aspectos- en la interpretación conforme a la Constitución, la integración de lagunas, y la habilitación al juzgador para hacer de legislador creando nuevos derechos o abrogando figuras vigentes. En este sentido, el principio de "inexcusabilidad" recogido en nuestra Constitución Política (art. 76 inc. II) obliga a los tribunales ordinarios al conocimiento y resolución de las cuestiones planteadas por las personas, aun cuando no exista ley que regule cómo y ante qué órganos recurrir para reclamar la afectación de derechos o intereses legítimos ${ }^{61}$. Por ello que a comienzos de la década de 1980, en Chile se reforzara la idea de que, en el ámbito constitucional, lo importante no es tanto un derecho subjetivo previamente existente cuanto el modo de ser de la protección judicial, con lo cual el momento procesal del sistema jurídico adquiere la máxima relevancia, especialmente para los derechos humanos, ya que éstos se juridizaron precisamente «desde el momento en que ha surgido el respectivo remedio procesal» ${ }^{62}$, remedio que la literatura nacional ha identificado con el recurso de protección ${ }^{63}$.

En Chile, la creación judicial del derecho fundamental a la imagen -vía recurso de protección- resulta un antecedente crucial a la hora de entender cómo este instituto pasó desde la iusprivatística chilena a incardinarse, luego, en el debate constitucional chileno de fines del siglo XX, y hasta hoy. Sin embargo, justificar el derecho a la imagen como fundamental sólo porque la práctica forense acudió a la acción de protección para reclamar de los abusos realizados por medio de retratos -en vez de configurar una

60 Corral Talciani, "Algunas reflexiones sobre la Constitucionalización del Derecho privado", 5-6.

61 Humberto Nogueira Alcalá, "La constitucionalización del proceso: el acceso a la jurisdicción, tutela judicial efectiva o debido proceso", La constitucionalización del Derecho chileno, coord. Juan Carlos Ferrada Bórquez (Santiago: Editorial Jurídica de Chile-Universidad Austral de Chile, 2003), I74-I75.

62 Cf. Alejandro Guzmán Brito, "La naturaleza de las garantías constitucionales de la persona examinada a través de su protección judicial”, Revista de Derecho y Jurisprudencia y Gaceta de los Tribunales $8_{5}, \mathrm{n}^{\circ} 2$ (I988): 105-го6.

63 Cf. Cea Egaña, "La constitucionalización del Derecho", I3. 
medida cautelar procesal pertinente- no resulta un argumento convincente; mucho menos definitivo. $\mathrm{Y}$ es que desde hace un par de décadas que la doctrina chilena viene denunciando la confusión que el recurso de protección ha generado entre «la jurisdicción constitucional y la común, abriendo un camino, expedito e informal, para llevar toda clase de asuntos hasta las Cortes; pretextando, para ello, cualquier afectación como lesión de un derecho» ${ }^{64}$. Como explica Eduardo Aldunate ${ }^{65}$, al no estar todos los derechos amparados por el art. 20 CPR y, al mismo tiempo, al no existir mecanismos jurídicos idóneos de protección de derechos y posiciones jurídicas a nivel del juez de letras, el amparo para derechos y posiciones jurídicas "no fundamentales" se busca a través de su inclusión como categoría dentro de algún derecho fundamental ya reconocido, especialmente en el derecho a la vida privada y en el derecho de propiedad sobre las cosas incorporales ${ }^{66}$, práctica que ha favorecido la "vulgarización" ${ }^{67}$ de nuestro Derecho toda vez que ni la Constitución ni la ley han colmado el contenido de los derechos fundamentales, sino que han sido los tribunales de justicia quienes los terminan configurando normativamente, desformalizando el Derecho chileno al construir jurisprudencia basada en la pura equidad para el caso concreto sin pretensiones de generalidad ni abstracción como, tampoco, de influir en cuanto precedente judicial. Esto es precisamente lo que ha pasado con el derecho a la imagen el cual paradójicamente se considera un derecho autónomo ${ }^{68}$, pero que al momento de fundamentarlo busca referencia y refugio dentro del contenido protectivo de otros derechos fundamentales como son los que resguardan la honra y la vida privada o la propiedad.

No obstante lo anterior, hay que reconocer que el derecho a la imagen se constitucionalizó sólo cuando el recurso de protección se transformó en tendencia, abriendo la puerta para acceder derechamente a la justicia constitucional, concentrando su amparo en la función cautelar de las Cortes de Apelaciones y la Corte Suprema, de ahí que este instituto sea

64 Gastón Gómez Bernales, Derechos fundamentales y recurso de protección (Santiago: Universidad Diego Portales, 2005), 23.

65 Cf. Aldunate Lizana, Derechos..., 202 y $36_{5}$.

66 Así en SCA de Valdivia 2²-20I8, del 6 de marzo de $20 \mathrm{I} 8$.

67 Andrés Bordalí Salamanca, "El recurso de protección chileno al banquillo", IUS Revista del Instituto de Ciencias Jurídicas de Puebla, A.C. $5, \mathrm{n}^{\circ} 27$ (2011): 59.

68 En Chile es prácticamente unánime el acuerdo en torno a la autonomía del derecho a la propia imagen. Por todos, cf. Emilio Pfeffer Urquiaga, "Los derechos a la intimidad o privacidad, a la honra y a la propia imagen. Su protección frente a la libertad de opinión e información”, Ius et Praxis 6, $\mathrm{n}^{\circ} \mathrm{I}(2000):{ }_{4} 69$. 
tributario de la jurisprudencia de éstas desde sus inicios ${ }^{69}$, en su desarrollo ${ }^{70}$ y hasta hoy.

\section{El derecho a la imagen como libertad de retrato}

\section{Derecho a la imagen: ¿extrapatrimonial?}

Ante el Derecho occidental, el moderno reconocimiento y construcción del derecho a la imagen da cuenta de tres etapas claramente distinguibles: la primera, vinculada a la propiedad intelectual sobre los retratos; la segunda, determinada por su recepción en el seno del Derecho civil; y la tercera, por su elevación al plano constitucional ${ }^{71}$.

Ante el Derecho chileno, dicho peregrinaje ha resultado idéntico, aunque con ciertas particularidades. De hecho -y salvo la mención en el Código del Trabajo-, no existe un reconocimiento expreso del derecho a la imagen, a diferencia de lo que ocurre en el ámbito comparado iberoamericano en donde se ha incluido en diferentes Constituciones y varios Códigos Civiles como el peruano (art. 15), boliviano (art. 16) y recientemente el argentino (arts. 52 y 53). En cuanto implícito, la dogmática chilena se ha valido en su construcción de dispersos antecedentes de texto positivo, erigiéndolo como uno más de los denominados derechos de la personalidad o "personalísimos", categoría propia del Derecho civil ${ }^{72}$. En efecto, desde comienzos del siglo anterior que este sector de la ciencia jurídica viene reivindicando -junto a los "atributos de la personalidad" ${ }^{73}$ - un conjunto de prerrogativas cuya característica principal consiste en estar excluidas del tráfico comercial. Santos Cifuentes define a los derechos personalísimos como aquellos «derechos subjetivos privados, innatos y vitalicios que tienen por objeto manifestaciones interiores de la persona y que, por ser inherentes, extrapatrimoniales y necesarios, no pueden transmitirse ni disponerse en forma absoluta y radical $\gg^{74}$. Clásicamente, se han identificado como tales el derecho a la vida, al honor, a la privacidad y a la imagen, entre otros.

69 Así lo ha sostenido invariablemente nuestra jurisprudencia desde el comienzo de la vigencia de la actual Constitución: "obtener y utilizar la propia imagen es un derecho de la persona o de la personalidad; algo esencial, natural e innato a todo individuo por el solo hecho de serlo y que, como tal, no necesita de un reconocimiento explícito de la ley”, SCA de Santiago $3^{2-82,}$ de 5 de julio de ig82.

70 Cf. Pedro Anguita Ramírez, "Jurisprudencia constitucional sobre el derecho a la propia imagen y a la vida privada en Chile (I98I-2004): un intento de sistematización”, Libertad de expresión en Chile, edit. Felipe González (Santiago: Facultad de Derecho, Universidad Diego Portales, 2006), $3^{22 .}$

71 Cf. Azurmendi Adarraga, "El derecho a la propia imagen...", 49 y ss.

72 Cf. Fueyo Laneri, Instituciones..., I7-30.

73 Sobre la diferencia teórica entre "atributos de la personalidad" y "derechos de la personalidad", cf. Cifuentes, Derechos..., 22I-222.

74 Cifuentes, Derechos..., I96 y 200. 
La literatura chilena ha ido definiendo estos derechos personalísimos en base a características consideradas insoslayables: inherentes ${ }^{75}$, universales ${ }^{76}$, absolutos ${ }^{77}$, subjetivos privados $^{78}$ y extrapatrimoniales. Determinante ha resultado la defensa de esta última cualidad. Guzmán Brito, por ejemplo, señala que el hecho de ser persona es el título que hace sinónimas las expresiones "derechos humanos", "de la personalidad" y "extrapatrimoniales", aunque ésta sería la terminología comprensiva de todas las anteriores, y la recomendada, al resaltar la característica más notable de éstos: carecer de contenido pecuniario $^{79}$. Para el derecho a la imagen, el medio chileno ha defendido firmemente que «de acuerdo a nuestro Código Civil, la imagen personal siempre estará ligada a la esencia de la persona humana, y por ello, nunca será un bien del cual su titular pueda usar, gozar y disponer, de acuerdo a las facultades que otorga la ley común al dueño de una cosa. La imagen humana está íntimamente ligada a su titular, y por ello pasa a formar parte de los denominados derechos de la personalidad, los cuales, de acuerdo a las directrices básicas del iusnaturalismo nacen, existen y mueren intrínsecamente unidos a la persona humana. Por ello, es solo cosa de revisar cada una de las características comunes a los derechos de la personalidad para observar que el derecho a la propia imagen no solo reúne tales cualidades, sino que, sin temor a equivocarnos, puede ser el más característico de los derechos de la personalidad $\gg^{80}$. A mi juicio, sin embargo, el tratamiento del derecho a la imagen como extrapatrimonial ha terminado por darle una configuración al margen de toda dog-

75 Pues la dignidad sería su fuente y fundamento, cf. Alberto Lyon Palma, Personas naturales, 80.

Ya que ningún ser humano puede ser excluido de su goce y ejercicio, Arturo Alessandri y Manuel Somarriva, Tratado de Derecho Civil, ${ }_{4}^{8} 5_{5}^{-4} 86$.

77 Ya que lo que los caracteriza es la existencia de un sujeto pasivo universal obligado a un deber general y negativo de abstención, tal como ocurre con los derechos reales, cf. Hernán Corral Talciani, "Configuración jurídica del derecho a la privacidad II: concepto y delimitación”, Revista Chilena de Derecho 27, $\mathrm{n}^{\circ} 2$ (2000): 355. Para Alejandro Guzmán, sin embargo, los derechos de la personalidad son personales y relativos, desde que no existe un único deber general de abstención, sino muchas "obligaciones cumulativas", es decir, tantas obligaciones y deudores como miembros de sociedad, cf. Alejandro Guzmán Brito, Las cosas..., 86.

78 La tendencia a calificar como "subjetivos" los derechos personalísimos está sumamente arraigada en nuestro medio, cf. Jorge López Santa María, "Consideraciones sobre el derecho a la privacidad o al secreto de la vida privada”, Revista de Derecho y Jurisprudencia y Gaceta de los Tribunales $79, \mathrm{n}^{\mathrm{o}} 3$ (I982): 69 .

79 Guzmán Brito, Las cosas..., 55. Consecuencia de esta última cualidad, es que sean declarados, también, como intransmisibles, imprescriptibles e inembargables, cf. Fueyo Laneri, Instituciones..., 17 y $3^{2}$.

80 Christian Vidal Beros, "La protección del derecho a la propia imagen como derecho de la personalidad en un mundo globalizado”, AA.VV. XXXV Jornadas de Derecho Público. El Derecho Público chileno y la globalización, Tomo I (Valparaíso: Edeval, 2006), 536. 
mática, ya civil, ya constitucional. Desde esta última vereda, por ejemplo, la construcción del derecho fundamental a la imagen como un extrapatrimonial resulta inútil desde que los derechos fundamentales no son traficables ni comerciables ${ }^{81}$. Hipótesis diferente es que ejerciendo tal derecho fundamental, ante el Derecho privado chileno, las personas puedan obligarse y traficar o comerciar derechos subjetivos, hipótesis que se comprueba al constatar lo realizado diariamente por nuestra práctica forense y lo reconocido por nuestros tribunales ${ }^{82}$, la interpretación sistemática de la normativa infraconstitucional chilena referida a la creación, uso y abuso de retratos o las propuestas de lege ferenda en dicho ámbito, por ejemplo, como lo señalado últimamente por el Servicio de Impuestos Internos respecto a la tributación de aquellas personas que perciben ingresos por vincular sus retratos o "imagen" a la publicidad de productos en redes sociales digitales ${ }^{83}$.

Ciertamente, si atendemos a la doctrina jurídica tradicional -y de prevalencia en nuestro medio- descubrir las cualidades de traficabilidad y patrimonialidad en el derecho a la imagen aparece a priori como una empresa inviable toda vez que -por definición- es personalísimo y extrapatrimonial ${ }^{84}$. Que el Código del Trabajo reconozca la posibilidad de comerciar con él sería la excepción que confirma la regla. A mayor abundamiento, el Código Civil chileno es vivo ejemplo de la tradición técnico-jurídica del concepto romano de cosa incorporal, el cual sólo incluía en el patrimonio a las dotadas de traficabilidad, de ahí que Guzmán Brito -asumiendo que los personalísimos pueden ser derechos- sentencie que la expresión extrapatrimoniales «[s]ignifica desde luego lo que literalmente expresa, es decir, que los derechos en examen están fuera del patrimonio. Se quiere significar además que los mismos son ajenos al comercio y a la circulación. Finalmente, que no son avaluables en dinero. En suma, que no son bienes» ${ }^{85}$. Teniendo esto en consideración, resulta evidente el distanciamiento y la falta de adecuación que existe entre esta tradicio-

81 Aldunate Lizana, Derechos..., 57, nota a pie de página $n^{\circ} 97$.

82 Respecto al tráfico y comercio de derechos de imagen, cf. Cristian Larraín Páez, "Actos y contratos sobre el derecho a la imagen en el ordenamiento chileno (con referencia al derecho comparado)", Revista Derecho de Valdivia $30, \mathrm{n}^{\circ}$ I (20I7): $53^{-76}$.

83 "El SII por primera vez fiscalizará las ganancias de los influencers", Tr3, acceso el I8 de marzo de 20rg, https:/www.tr3.cl/noticia/negocios/el-sii-primera-vez-fiscalizara-ganancias-influencers

84 O “incomerciable" en la terminología de David Stitchkin Branover, "Los bienes extrapatrimoniales", Revista de Derecho de la Universidad de Concepción 29, $\mathrm{n}^{\circ}$ II5 (I96I): 27-28. La iusprivatística chilena, casi sin excepciones, se ha pronunciado en favor de esta tesis: Fueyo Laneri, Insituciones..., 69-77; Lyon Palma, Personas..., 80; Gonzalo Figueroa Yañez, "Los derechos de la personalidad en general: concepción tradicional”, Revista de Derecho de la Pontificia Universidad Católica de Valparaíso I9 (I998): 24-25; Enrique Barros Bourie, Tratado de Responsabilidad Extracontractual (Santiago: Editorial Jurídica de Chile, 2006), 564; Alessandri y Somarriva, Tratado..., ${ }_{4} 86$.

Guzmán Brito, Las cosas..., 55-56 y I5. En el mismo sentido, cf. Daniel Peñailillo Arévalo, Los bienes, la propiedad y otros derechos reales, Reimpresión de la i a ed. (Santiago: Editorial Jurídica, 2009), 6I-62. 
nal dogmática aplicada al derecho a la imagen y la realidad jurídica, máxime los tiempos que corren en donde la cesión de derechos de imagen es una convención reconocida en diversas legislaciones ${ }^{86}$, e incluso en Chile, no obstante que dicho reconocimiento sea tímido y confuso ${ }^{87}$.

Esta confusión proviene de la intención por compatibilizar los derechos personalísimos con el concepto de patrimonio ${ }^{88}$. En nuestro país ya, a mediados del siglo XX, comenzó a forjarse una tendencia doctrinaria que -sin pretender subvertir el esquema de los derechos personalísimos en cuanto extrapatrimoniales- reconocía la posibilidad de tráfico y comercio en alguno de ellos, tendencia que a partir de la década de 1980 vino a encontrar respaldo en la jurisprudencia constitucional chilena, especialmente con ocasión del ejercicio del recurso de protección. Sin embargo, aun así la justificación resulta compleja de entender. Desde ya, la terminología es errática pues se continúa hablando indistintamente de derechos personalísimos, fundamentales, de la persona, etcétera. Luego, para avalar las cesiones o liberalidades -operadas en el ámbito del Derecho privado- se apeló a la figura de la renuncia, bajo la condición de que ella tuviera "una causa legítima" ${ }^{9}$. Sin embargo, como seguía pendiente la justificación de su comercio, para el caso particular del derecho a la imagen se construyó una estructura dual que distinguía una faceta "patrimonial" o "positiva", y otra "extrapatrimonial" o "negativa", estructura denominada "bipolar"90. La extrapatrimonial es reconocida a todas las personas y tendría amparo constitucional. El otro, el aspecto "patrimonial”, permitiría el tráfico y comercio de los derechos de imagen, aunque sólo a aquellas personas que lucran con ella ${ }^{91}$ y no contaría con amparo constitucional porque el dogma dice que se trata de un derecho personalísimo y extrapatrimonial ${ }^{92}$.

86 Particularmente en España, cf. Carlos Vendrell Cervantes, El mercado de los derechos de imagen (Madrid: Aranzadi Editorial, 20I5).

87 Mediante el oficio $\mathrm{N}_{4}^{\circ} \cdot 8_{4}$, del 28 de octubre de 2004 , el Servicio de Impuestos Internos se pronunció ya sobre la obligación de tributar, en Chile, por las rentas obtenidas como consecuencia de la cesión de derechos de imagen: "la remuneración obtenida por un jugador de fútbol por su participación en un spot publicitario y sesión de fotos, efectivamente corresponde a un ingreso que se clasifica en el número $2^{\circ}$ del artículo $4^{\circ}{ }^{\circ}$ de la ley sobre Impuesto a la Renta, pues proviene del ejercicio de una ocupación lucrativa”.

88 Cf. Stitchkin Branover, "Los bienes extrapatrimoniales”, II-I3.

89 Por todos, cf. Lyon Palma, Personas..., 80.

90 Se trata de una tesis originada en el Derecho español y que ha tenido plena acogida en Chile, por ejemplo, en Humberto Nogueira Alcalá Derechos fundamentales y garantías constitucionales, $3^{\mathrm{a}}$ ed., Tomo I (Santiago: Librotecnia, 2010), 756 y ss.

91 Supuestamente aquellas personas consideradas famosas, celebridades o personajes públicos.

92 Cf. Humberto Nogueira Alcalá, "El derecho a la propia imagen como derecho fundamental implícito. Fundamentación y caracterización”, Revista Ius et Praxis 13, n 2 (2007): 272. 
La anterior da cuenta de una construcción no sólo artificial, sino derechamente innecesaria. Es como si para el Derecho de autor se reconociera protección constitucional únicamente para los derechos morales y no para los patrimoniales, en condiciones que el art. $19 \mathrm{~N}^{\circ} 25 \mathrm{CPR}$ no discrimina. Es por esto que, a mi juicio, la consideración del derecho a la imagen en cuanto libertad, autodeterminación para crear retratos, permite explicar de mejor manera el fenómeno de la creación y tráfico de imágenes de personas, sin necesidad de subvertir el esquema tradicional de los personalísimos, ni tampoco inventarle "facetas" o "polos" al derecho en cuestión.

\section{Críticas al recurso de protección como medida cautelar ad hoc del derecho a la imagen}

En la actualidad, el rol de la acción de protección se muestra insuficiente. En mi perspectiva, la justificación de la fundamentalidad del derecho a la imagen sólo porque es reconocido y amparado por el recurso de protección se ha vuelto un argumento tautológico y redundante. Según mi parecer, esta acción se muestra ineficiente e ineficaz si se trata de solucionar los reclamos por usos y abusos de retratos planteados ante las Cortes de Apelaciones. Las razones son diversas:

A. Falta de reconocimiento constitucional del derecho a la imagen. La ausencia del catálogo constitucional conlleva una dificultad básica para operar el recurso de protección, pues al no figurar en el art. 19 nadie podría accionar a causa de actos $u$ omisiones arbitrarios o ilegales que impliquen la "privación, perturbación o amenaza en el legítimo ejercicio" de su derecho a la imagen. Esta interpretación se ve avalada por quienes sostienen que una vez descubiertas las libertades civiles innominadas éstas no tendrían necesariamente la misma configuración de las nominadas y, en consecuencia, el titular estaría imposibilitado de recurrir de protección al no estar designadas expresamente en el art. $20 \mathrm{CPR}^{93}$, a menos -claro está- que se fuerce su inclusión en otros derechos fundamentales, solución defendida por la dogmática chilena ${ }^{94}$. Incluso, hay quienes avalando recurrir de protección -en subsidio de otras acciones civiles o penales- previenen que ello no implica reconocerle el carácter de fundamental y/o constitucional a nuestro objeto de estudio ${ }^{95}$.

93 Solo quedarían amparadas por el recurso de inaplicabilidad y el resto de las acciones que el Derecho común o la legislación especial destinen a ellas, cf. Guzmán Brito, El Derecho..., 266.

94 Cf. Nogueira Alcalá, "El derecho a la propia imagen como derecho fundamental implícito. Fundamentación y caracterización”, 269-270; Hernán Corral Talciani, “Sobre la responsabilidad civil de los periodistas y de los medios de comunicación social por atentados a la honra, intimidad e imagen”, Información Pública $4, \mathrm{n}^{\circ} 2$ (2006): 260.

95 Cf. Corral Talciani, "Sobre la responsabilidad civil de los periodistas y de los medios de comunicación social por atentados a la honra, intimidad e imagen”, 260 . En contra de esta opinión, cf. Aldunate Lizana, Derechos..., 212-2I3. 
B. CUESTIONADA FUNCIÓN CAUTELAR DEL RECURSO DE PROTECCión. Al tratarse de un procedimiento de urgencia, se tiende a desconocer principios procesales básicos en su tramitación. Por ejemplo, como la sentencia recaída en el recurso de protección produce efecto de cosa juzgada formal ${ }^{96}$, el mismo asunto debería luego discutirse en un proceso de lato conocimiento, situación que rara vez ocurre ya que son las propias Cortes las que acaban zanjando la cuestión en un procedimiento breve, sumario ${ }^{97}$. Peor aún, pues es un diagnóstico extendido que la acción de protección no responde a las exigencias de sencillez, eficacia, alcance y puesta a disposición del ciudadano común que toda acción de tutela de derechos fundamentales debiera tener ${ }^{98}$.

C. DESACTUALIZACIÓN DEL PODER JUDICIAL EN MATERIAS VINCULADAS A LA PROPIEDAD INTELECTUAL Y AL DERECHO INFORMÁTICO. La fácil creación, reproducción, publicación y comunicación pública de imágenes demandan medidas cautelares que resulten oportunas y adecuadas para impedir la "viralización" de aquellas, cuestión que el recurso de protección no ha conseguido satisfacer debido a su vetusta estructura y tramitación. De hecho, ante la desesperación que ha provocado la avalancha de recursos de protección, por disputas ocurridas en el contexto de internet y concretamente en las redes sociales, no resulta extraño que las Cortes apliquen cautela "autosatisfactiva" 99 , aunque ciertamente el fantasma de la censura las llevará a dar preferencia al ejercicio de la libertad de expresión. Para ejemplificar, recurriré a un caso ocurrido durante el año 2013 y en el cual me correspondió colaborar en el informe del recurrido de protección ${ }^{100}$. En esa oportunidad, una corporación de Derecho privado recurrió de protección contra un ex trabajador -encargado de administrar las redes sociales de aquella- ya que al ser despedido comenzó a denunciar a sus ex empleadores a través de la página de Facebook que le correspondía administrar. La resolución de la cuestión era de mayor complejidad para la Corte de Apelaciones de Concepción pues

96 Cf. Andrés Bordalí Salamanca, "El recurso de protección: todavía un fantasma jurídico (Tribunal Constitucional)", Revista de Derecho Valdivia 27, $\mathrm{n}^{\mathrm{o}} 2$ (2014): 282.

97 Cf. Domínguez Águila, "Aspectos de la constitucionalización del Derecho civil chileno", I25-I27.

98 Cf. Humberto Nogueira Alcalá, "El recurso de protección en el contexto del amparo de los derechos fundamentales latinoamericano e interamericano", Revista Ius et Praxis $\mathrm{I}_{3}, \mathrm{n}^{\circ} \mathrm{I}$ (2007): 77 y $8 \mathrm{I}-82$.

99 Es decir, una medida cautelar urgente y sin consideración al parecer de la contraparte. Cf. Andrés Bordalí Salamanca, "El debido proceso civil”, La Constitucionalización del Derecho chileno, coord. Juan Carlos Ferrada Bórquez (Santiago: Editorial Jurídica de Chile-Universidad Austral de Chile, 2003), 288-289 y 293.

100 SCA de Concepción I80-20I3, de 9 de mayo de 2013. 
la recurrente no sólo pretendía que el trabajador se abstuviera de escracharla o "funarla" a través de internet, sino que paralelamente pretendía que el recurrido le entregara las claves de la cuenta en Facebook e, incluso, argumentaba que los contactos o "amigos" de dicha red social eran ya parte del inventario y capital de la empresa, alegando un derecho de dominio sobre ellos. Más difícil aun, pues la pretendida cuenta de Facebook había sido creada por el trabajador recurrido antes de ingresar a trabajar para la corporación, sólo que luego -una vez contratadoentregó esa cuenta en "aporte", cambiando el nombre de la misma en favor de la empresa, etapa en la que los "amigos" aumentaron de 2.500 a casi 5.000. Lamentablemente, la Corte de Concepción eludió toda esa discusión y sólo se limitó a rechazar el recurso indicando que: «desde la perspectiva anotada, no parece que el comportamiento del recurrido consistente en el cambio del nombre de su cuenta de Facebook y la publicación en ella de una carta del Sindicato de trabajadores de la corporación recurrente, puede considerarse que haya contrariado la libertad de expresión ni transgredido el ejercicio del derecho a difundir informaciones e ideas de toda índole, sin que se aprecie que se haya verificado un abuso de dicho ejercicio. No hay, por consiguiente, en la referida conducta un comportamiento que pueda calificarse de antojadizo o caprichoso o que vulnere algún precepto legal, dado que pues los actos ejecutados por el recurrido corresponden al legítimo ejercicio de su libertad de expresión, lo que necesariamente conduce a que la acción constitucional entablada no pueda prosperar».

Como muestra el ejemplo anterior, la acción de protección ha sido desbordada por la realidad y la masificación de las nuevas tecnologías. En el caso del derecho a la imagen, el hecho de que la cautela se otorgue solamente a partir de la reproducción o comunicación publicación de retrato -y no desde su creación- es muestra de aquello. No negaré que, en los hechos, es prácticamente imposible evitar la creación no consentida de un retrato, mas ello no debería motivar a desconocer que su contenido protectivo demanda amparo para evitar la mera fijación de la imagen. Este simple dilema acarrea una serie de dificultades procesales pues muchos recursos de protección ni siquiera sortean el examen previo de admisibilidad. Prueba de esto es la vacilante jurisprudencia que condiciona el cómputo del plazo y la oportunidad para incoar el recurso de protección a la eventual publicación o comunicación pública del retrato. El año 2003, por ejemplo, la C.A. de Santiago declaró inadmisible, por extemporáneo, un recurso de protección toda vez que la recurrente sólo reclamó de las últimas publicaciones que hizo el medio de información recurrido y no desde que se hizo la primera comunicación pública de las imágenes, cuestión que también había ocurrido años atrás ${ }^{101}$. En otro caso,

101 SCA de Santiago I36I-2003, de I4 de abril de 2003 . No obstante, interesante resulta, en este mismo fallo, el voto de minoría del abogado integrante, Emilio Pfeffer Urquiaga, quien estuvo por entrar al fondo del asunto discutido, teniendo para ello en consideración el hecho de que cada publicación del retrato constituye "un acto independiente" para efectos de contar el plazo de recurso. 
de ese mismo año 2003, la C.A. de Santiago aplicó un criterio distinto y acogió el recurso interpuesto, no obstante que, al momento de fallo, el recurrido ya había eliminado la fotografía infractora de su página web ${ }^{102}$. Años más tarde, la Corte Suprema -conociendo de la apelación de un recurso de protección- fallaría en sentido opuesto, es decir, negando amparo al derecho a la imagen toda vez que el recurrido, antes del fallo, ya había retirado las imágenes infractoras ${ }^{103}$. Mismo criterio aplicaría, el año 2015, la C.A. de Santiago cuando, frente a una solicitud de no exhibir imágenes del recurrente, rechazó el recurso al no existir actualidad en el acto u omisión, motivo por el cual el recurso "ha perdido oportunidad"104, posición que también defendería la Corte Suprema ese año pues al no existir comunicación pública del retrato en cuestión «no se divisa en la especie cautela urgente alguna que proporcionar por esta vía» ${ }^{105}$.

Por último, no podemos soslayar que las grandes empresas detrás de las redes sociales masivas -Facebook, Youtube, Instragram, Twitter, etc.- no registran domicilio en Chile, lo cual pone en jaque el imperio con que cuentan los tribunales chilenos, sumándose a las críticas ya esbozadas un dilema procesal transfronterizo -no menor ${ }^{106}$ - a la hora de conceder una orden de no innovar u otra medida cautelar concreta que pretenda el recurrente de protección para evitar la difusión de su imagen y la propagación del daño.

D. eXPRopiación de los derechos de propiedad intelectual. Vinculado a lo anterior, podemos formular una última crítica en relación al recurso de protección y las medidas dispuestas por las Cortes cada vez que se ordena la destrucción de aquellos retratos que vulneran el derecho a la imagen. Recientemente, por ejemplo, la Corte Suprema ha sentenciado: «[q]ue por lo anteriormente razonado y considerando la grave afectación a la honra de M., los recurridos estarán obligados a disponer o recuperar el registro digital con el contenido del anuario y de la caricatura, junto a su materialidad, esto es, los libros y el cuadro en que aparece la caricatura de la ofendida, debiendo el establecimiento educacional recurrido dirigir una comunicación a todos los

102 SCA de Santiago $12{ }_{4} 8-2003$, de in de junio de 2003.

103 SCSJ 25348 -2010, de 24 de febrero de 2010.

104 SCA de Santiago I435-20I5, de 9 de marzo de 2015.

105 SCSJ de Temuco 30023-20I4, de i2 de enero de 2015.

106 Para una aproximación a este último tópico, cf. Rodrigo León Urrutia, "Determinación de la ley aplicable al Derecho de Autor en el Convenio de Berna”, Temas actuales de propiedad intelectual. Estudios en homenaje a la memoria del profesor Santiago Larraguibel Zavala, coord. Marcos Morales Andrade (Santiago: Lexis Nexis, 2006), 77-93. 
apoderados y ex apoderados que tengan en su poder la revista y la mencionada sátira para que hagan devolución de aquella dentro de décimo día a fin de proceder a su íntegra destrucción, lo que se hará a costa del Colegio A. y en presencia de un notario público, de lo que se levantará una completa y detallada acta de todas las actuaciones desarrolladas» ${ }^{107}$.

En este punto, hay que tener en cuenta que la legislación chilena ${ }^{108}$ reconoce automáticamente derechos de autor al creador, sobre su obra, a partir del momento mismo de su creación, incluso si ese retrato se hizo contra la voluntad del efigiado. En el caso de una pintura o una caricatura, por su confección, ello toma cierto tiempo; no así con una fotografía o una videograbación, en donde la creación es instantánea. En concordancia, debemos considerar que la Constitución ampara la propiedad intelectual incluso ante la expropiación (art. 19 $\mathrm{N}^{\circ} 25 \mathrm{CPR}$ ). Entonces, cuando una Corte de Apelaciones o la Corte Suprema ordena la destrucción del retrato infractor, aparece el desafío de calificar jurídicamente dicha medida: ¿confiscación de bienes, comiso?; ¿expropiación por causa de utilidad pública? Sin duda, una cuestión relevante y que merece atención y resolución en nuestro medio ${ }^{109}$.

\section{Hacia una comprensión sistemática del derecho a la imagen: la libertad para crear retratos}

Todo lo dicho hasta ahora no logra justificar por qué, en Chile, el derecho a la imagen sea aceptado como fundamental e implícito. No obstante, sí permite avanzar en el entendimiento de que la sistematización de la normativa nacional -referida a la creación y tráfico de retratos- da cuenta de una reglamentación que se identifica plenamente con las llamadas libertades innominadas de Derecho privado, cuyas cuestiones arribaron al debate constitucional de nuestro país con ocasión del proceso de "constitucionalización" operado a partir de la década de 1980.

Previo a que el recurso de protección hiciera su debut en nuestro país, la jurisprudencia sobre derecho a la imagen era prácticamente nula, pues como apuntara Novoa Monreal -y hasta bien avanzado el siglo XX- como no podía obtenerse el retrato físico de una persona, sino a condición de que ella aceptara posar para el artista, era raro encontrar casos en que alguien reclamara del mal empleo de su imagen, y de ocurrir el problema podía ser resuelto sin graves dificultades apelando a los cánones de Derecho privado ${ }^{110}$. Y si bien en esos

107 SCSJ I672I-20I7, de 5 de diciembre de 2017.

108 Art. I, Ley $\mathrm{N}^{\circ}$ I7.336 sobre Propiedad intelectual.

109 Respecto a la expropiación, sigo a Santiago Larraguibel para quien sólo el derecho moral de autor no sería expropiable ante la Constitución de ig80, cf. Santiago Larraguibel Zavala, Tratado de marcas comerciales. (Santiago: Editorial Jurídica, 1987), 44 .

110 Cf. Eduardo Novoa Monreal, Derecho a la vida privada y libertad de información. Un conflicto de derechos. $2^{\text {a }}$ ed. (México: Siglo XXI Editores S.A., I98I), 64. 
años -ni hoy tampoco- existía una comprensión sistemática del fenómeno del retrato de personas, es innegable que la ciencia jurídica se valió de diversos antecedentes normativos para proponer remedios procesales a los conflictos sobre abusos cometidos en la creación y tráfico de imágenes de personas, enfoque que gravitó en torno al estatuto sobre responsabilidad extracontractual, regulado en los artículos 2314 y ss. del Código Civil, básicamente por consideración a las características de generalidad y abstracción de este régimen y en atención al principio general neminem laedere o de "no dañar injustamente a otro"111. Mi crítica es que, bajo ese panorama, las posibilidades de reparación al derecho a la imagen quedan reducidas sólo a una eventual responsabilidad extracontractual del infractor por el daño moral causado, excluyendo los daños materiales y la posibilidad de responsabilidad civil contractual. Sin ir más lejos, en la actualidad los esfuerzos dogmáticos están abocados precisamente a solucionar sólo este tipo de daño o menoscabo sufrido por el titular del derecho a la propia imagen ${ }^{112}$. Incluso existen proyectos de ley en este último sentido, como aquel presentado en el año 2013 y que pretende modificar "el Código Civil, con el objeto de regular la procedencia de la indemnización del daño moral por atentados a la honra, la vida privada y la imagen personal"113, soslayando otras posibilidades de daño -i.e daño emergente, lucro cesante,- y especialmente el reconocimiento de responsabilidad contractual que cabe en el tráfico y cesión de derechos de imagen.

Evidentemente, Chile requiere de un reconocimiento explícito del derecho fundamental a la imagen y, ante todo, que se le considere autónomo en relación al derecho a la vida privada. Mientras ello no ocurra, seguirá relegado al ámbito de los derechos personalísimos y extrapatrimoniales, negándose las posibilidades de traficar y comerciar a su respecto. Al mismo tiempo, se requiere de un remedio procesal y pertinente a los tiempos que corren. Tras el advenimiento de la constitucionalización y la universalización de los derechos humanos en Chile, quedó en evidencia que no existían mecanismos jurídicos cautelares idóneos para que los jueces de letras brindaran debida protección a aquellos ${ }^{114}$, momento en que el recurso

111 Cf. Hernán Corral Talciani, "Derechos al honor, vida privada e imagen y responsabilidad civil por los daños provocados por empresas las periodísticas”, Revista de Derecho Universidad Católica de la Santísima Concepción $5, \mathrm{n}^{\circ} 5$ (1996): 86-87; José Ignacio Peña Atero, "La protección del Derecho a la propia imagen”, Revista de Derecho Público de la Facultad de Derecho de la Universidad de Chile 64 (2002): 305 .

112 Así, por ejemplo, en Cristián Larraín Páez, "Responsabilidad civil por vulneración del derecho a la imagen: análisis comparado y propuestas para el Derecho chileno”, Revista Chilena de Derecho Privado 26 (2016): II9-I85.

113 Boletín $\mathrm{N}^{\circ}$ 9107-07, moción parlamentaria ingresada el ı2 de septiembre de 2013.

114 A diferencia, según Bordalí Salamanca, de lo que ocurre en el Derecho comparado donde, en varias legislaciones, se le encarga la cautelar de los derechos fundamentales a la jurisdicción civil ordinaria, cf. Andrés Bordalí Salamanca, "El recurso de protección entre exigencias de urgencia y seguridad jurídica", Revista de Derecho Valdivia I9, no 2 (2006): 2I0-2II. 
de protección se ofreció como la vía idónea para la protección de derechos y posiciones jurídicas, fundamentales o no. Para el caso del derecho a la imagen, esto fue de suma utilidad. Sin embargo, hoy sólo se trata de una injustificada e insostenible dependencia ${ }^{115}$.

La falta de una comprensión sistemática sobre el fenómeno de la creación de retratos y el tráfico de derechos de imagen permite a la dogmática chilena afirmar que nuestra legislación no cuenta con un remedio cautelar $a d h c^{116}$, debiendo acudirse al recurso de protección devenido en sustituto de otras acciones especiales -civiles, penales, administrativas, etcétera ${ }^{117}$ - que podrían resolver los conflictos sobre abusos en la creación o tráfico de retratos, ya entre particulares, ya entre los particulares y el Estado. Sostengo esto pues existen suficientes antecedentes normativos que demuestran que el derecho a la imagen se encuentra ya regulado infraconstitucionalmente, incluso con anterioridad a la entrada en vigencia de la Carta de 1980. Aunque, y ante todo, habrá que recordar que a falta de un remedio cautelar específico, los operadores jurídicos pueden acudir subsidiariamente al procedimiento ordinario del Código de Procedimiento Civil (art. 3) y desarrollar acciones cautelares innominadas ${ }^{118}$. De hecho, aunque sorprenda, esto ya se ha ensayado. En su momento, por ejemplo, una de las opciones más consideradas -para reclamar infracciones al derecho a la imagen- fue acudir a las acciones contempladas en la Ley $\mathrm{N}^{\circ} 16.643$ sobre abusos de publicidad ${ }^{119}$, remedios heredados por la Ley $\mathrm{N}^{\circ} 19.733$, la que en el inc. I de su art. 39 prescribe: «la responsabilidad penal y civil por los delitos y abusos que se cometan en el ejercicio de las libertades que consagra el inciso primero del número $12^{\circ}$ del artículo 19 de la Constitución Política de la República, se determinará por las normas de esta ley y las de los Códigos respectivos», en concordancia con el inc. I del art. 40 de la misma ley: «la acción civil para obtener la indemnización de daños y perjuicios derivada de delitos penados en esta ley se regirá por las reglas generales». Los tribunales dan cuenta de esto, en el sentido de remarcar la existencia de acciones pertinentes, evitando el abuso del recurso de protección. Así, por ejemplo, durante el año 2005 la C.A. de Santiago proponía cautelar el derecho a la imagen mediante la remisión a acciones diferentes al recurso de protección: «que el derecho a la propia imagen, es protegido por otras vías o acciones recogidas en determinados cuerpos legales específicos, que garantizan 'el derecho a la imagen', incluso

115 Cf. Peña Atero, “La protección del derecho a la propia imagen”, 298.

116 Cf. Pfeffer Urquiaga, "Los derechos a la intimidad o privacidad, a la honra y a la propia imagen. Su protección frente a la libertad de opinión e información”, 474.

117 Cf. Gómez Bernales, Derechos..., «3; Domínguez Águila, "Aspectos de la constitucionalización del Derecho Civil chileno", I23-I25.

118 Cf. Bordalí Salamanca, "El recurso de protección entre exigencias de urgencia y seguridad jurídica", 209 y 224.

119 Cf. Salvador Caro Romero, "El Derecho a la propia imagen”, Revista de Derecho Universidad Católica de la Santísima Concepción 7 (r999): 2r6. 
en los casos que se efectúen por medios de comunicación de masas, como pueden ser: los periódicos, revistas, radios, tv, etcétera ${ }^{120}$. La misma Corte, esta vez durante el año 2012, sentenció que: «la vulneración de derechos que por las recurrentes se dicen lesionados, provendría de un acuerdo entre las partes destinado a producir consecuencias jurídicas; y su protección jurídica, en cuanto a los efectos, debe hacerse por medio del ejercicio de las acciones civiles correspondientes; estatuto jurídico procesal que protege los derechos de toda persona previo proceso judicial» ${ }^{121}$. Misma opinión reiteraría, años después, al declarar inadmisible una acción que versaba sobre el derecho a la imagen, indicando que «[1]os hechos descritos sobrepasan los márgenes del recurso de protección, toda vez que ellos dicen relación con la existencia de un contrato con la recurrida, cuestión que debe ser debatida, probada y resuelta en el procedimiento judicial que corresponda» ${ }^{122}$.

Lamentablemente, revisando la jurisprudencia chilena de las últimas cuatro décadas se puede constatar que la creatividad en el desarrollo de acciones destinadas a precaver infracciones al derecho a la imagen ha sido prácticamente nula, por ello que el recurso de protección siga siendo la herramienta procesal por excelencia al momento de solucionar los conflictos respecto a esta prerrogativa. En mi opinión, eso sí, debiera avanzarse en el reconocimiento legislativo de una acción cautelar ad hoc, toda vez que el derecho a la imagen no sólo ampara a las personas ante la publicación o comunicación pública de retratos, sino que ante la mera creación como ha ocurrido, por ejemplo, en Italia donde se han venido desarrollando medidas cautelares de urgencia para los procesos civiles, a fin de evitar el perjuicio inminente -e irreparable- del derecho a la imagen ${ }^{123}$. Al mismo tiempo, no hay que perder de vista que toda persona, en ejercicio de su libertad de retrato, puede generar derechos subjetivos e involucrarse en comercio y cesión de derechos de imagen, por ello que -a mi juicio- la regulación dada por la legislación chilena al derecho a la imagen da cuenta de una "garantía de instituto" al contemplar y atribuir un ámbito de competencias a los individuos respecto a su imagen, es decir, les reconoce la posibilidad de actuar esa libertad creando efectos jurídicos ${ }^{124}$.

120 SCA de Santiago 60/4-2005, de i6 de noviembre de 2005 .

121 SCA de Santiago 8435-2012, de 29 de noviembre de 2012.

122 SCA de Santiago I46.986-20I3, del ${ }_{4} 4$ de febrero de 20I4. La inadmisibilidad había sido declarada por la Corte el rg de diciembre de 2013 .

123 Cf. Pietro Sirena, "Il sequestro della stampa a tutela del diritto all'immagine", La nuova giurisprudenza civile commentata 2 (2008): $\mathrm{I}_{3} 5^{-\mathrm{I}_{4}}{ }^{2}$.

124 Para una referencia respecto a la inclusión de la teoría sobre las "garantías institucionales y de instituto", en Chile, véase Eduardo Aldunate Lizana y Jessica Fuentes Olmos, "El concepto del derecho de propiedad en la jurisprudencia constitucional chilena y la teoría de las garantías de instituto", Revista de Derecho de la Universidad Católica de Valparaíso I8 (I997): 195-221; Jessica Fuentes Olmos, El derecho de propiedad. (Santiago: Ediciones Der, 20I8): 233-260. 


\section{CONCLUSIONES}

1. En Chile, la conducta de retratar personas viene siendo regulada, al menos, desde la entrada en vigencia del Código Civil.

2. Durante el siglo XX, el reconocimiento de un derecho a la imagen tuvo lugar al amparo del Derecho civil sobre las personas.

3. Antes de la entrada en vigencia de la Constitución de 1980, el derecho a la imagen era sólo considerado como un derecho personalísimo y extrapatrimonial.

4. Tras el proceso denominado "constitucionalización del Derecho civil" -y concretamente mediante el uso del recurso de protección- el derecho a la imagen fue reconocido como fundamental por la jurisprudencia de las Cortes de Apelaciones y la Corte Suprema.

5. La ausencia de un reconocimiento constitucional explícito del derecho a la imagen dificulta su justificación en cuanto fundamental, más aún si para accionar de protección resulte obligatorio presentarlo como accesorio al derecho a la vida privada, honra o propiedad.

6. La masificación de las tecnologías que permiten la creación, reproducción y comunicación pública de retratos demandan una medida cautelar ad hoc para los casos de infracción al derecho a la imagen, toda vez que la acción constitucional de protección se muestra ineficiente a la hora de precaver lesiones o menoscabos vinculados a esas conductas.

7. La compresión del derecho a la imagen como libertad para crear retratos -"libertad de retrato"- como, asimismo, el abandono de su consideración como personalísimo y extrapatrimonial, permite explicar de manera satisfactoria las distintas relaciones jurídicas que pueden existir respecto a la creación de retratos como, también, a su tráfico y comercio.

8. De lege ferenda urge un reconocimiento constitucional del derecho a la imagen -en cuanto fundamental y autónomo- en concordancia con el diseño de acciones o medidas cautelares pertinentes para prevenir los abusos que, valiéndose de retratos de personas, ocurren diariamente en el contexto de internet y las redes 


\section{BIBLIOGRAFÍA}

- $\quad$ sociales.

Aillapán Quinteros, Jorge. "Derecho a la propia imagen: ¿derecho personalísimo?, ¿derecho fundamental? Precisiones terminológicas para el ordenamiento jurídico chileno". Revista Chilena de Derecho 43, $\mathrm{n}^{\circ} 2$ (2016): 433-459.

Aillapán Quinteros, Jorge. "Interés público informativo y minusvaloración del derecho a la imagen de un político en Chile".

Revista Boliviana de Derecho 25 (2018): 110-143.

Aldunate Lizana, Eduardo y Jessica Fuentes Olmos, "El concepto del derecho de propiedad en la jurisprudencia constitucional chilena y la teoría de las garantías de instituto". Revista de Derecho de la Universidad Católica de Valparaíso 18 (1997): 195-221.

Aldunate Lizana, Eduardo. "El efecto de irradiación de los derechos fundamentales". La Constitucionalización del Derecho chileno, coord. por Juan Carlos Ferrada Bórquez. Santiago: Editorial Jurídica de Chile-Universidad Austral de Chile (2003): 13-38.

Aldunate Lizana, Eduardo. Derechos fundamentales. Santiago: LegalPublishing, 2008.

Alessandri, Arturo, y Manuel Somarriva. Tratado de Derecho Civil, partes preliminar y general, Tomo I. Santiago: Editorial Jurídica de Chile, 2010.

Alexy, Robert. Teoría de los derechos fundamentales. $2^{\mathrm{a}}$ reimpresión de la $2^{a}$ edición en español. Traducido por Carlos Bernal Pulido. Madrid: Centro de Estudios Constitucionales, 2012.

Anguita Ramírez, Pedro. "Jurisprudencia constitucional sobre el derecho a la propia imagen y a la vida privada en Chile (1981-2004): un intento de sistematización". Libertad de expresión en Chile, edit. Felipe González. Santiago: Facultad de Derecho, Universidad Diego Portales (2006): 319-521.

Azurmendi Adarraga, Ana. El derecho a la propia imagen: su identidad y aproximación al derecho a la información. $2^{\mathrm{a}}$ ed. México D.F.: Universidad Iberoamericana, Biblioteca Francisco Xavier Clavigero, 1998.

Barros Bourie, Enrique. Tratado de responsabilidad extracontractu- 
- al. Santiago: Editorial Jurídica de Chile, 2006.

Bordalí Salamanca, Andrés. "El debido proceso civil". La constitucionalización del Derecho chileno, coord. Juan Carlos Ferrada Bórquez. Santiago: Editorial Jurídica de Chile-Universidad Austral - de Chile (2003): 251-295.

Bordalí Salamanca, Andrés. "El recurso de protección entre exigencias de urgencia y seguridad jurídica". Revista de Derecho Valdivia

- 19, $\mathrm{n}^{\circ} 2$ (2006): 205-228.

Bordalí Salamanca, Andrés. "El recurso de protección chileno al banquillo". IUS Revista del Instituto de Ciencias Jurídicas de Puebla, - A.C. $5, \mathrm{n}^{0} 27$ (2011): 56-71.

Bordalí Salamanca, Andrés. "El recurso de protección: todavía un fantasma jurídico (Tribunal Constitucional)". Revista de Derecho

- Valdivia 27, no 2 (2014): 277-283.

Caro Romero, Salvador. "El Derecho a la propia imagen". Revista de Derecho Universidad Católica de la Santísima Concepción 7 (1999):

- 213-218.

Cea Egaña, José Luis. "La constitucionalización del Derecho". Revista de Derecho Público de la Facultad de Derecho de la Universidad de - Chile 59 (1996): 11-22.

Cea Egaña, José Luis. Derecho Constitucional chileno, Tomo II, $2^{\text {a }}$ ed. actualizada. Santiago: Ediciones Universidad Católica de Chile, - 2012.

Cifuentes, Santos. Derechos personalísimos. $2^{\text {a }}$ edición actualizada y - ampliada. Buenos Aires: Editorial Astrea, 1995.

Corral Talciani, Hernán. "Derechos al honor, vida privada e imagen y responsabilidad civil por los daños provocados por empresas las periodísticas". Revista de Derecho Universidad Católica de la Santí- sima Concepción 5, nº 5 (1996): 73-96.

Corral Talciani, Hernán. "Configuración jurídica del derecho a la privacidad II: concepto y delimitación”. Revista Chilena de Derecho - $27, n^{\circ} 2$ (2000): 331-355.

Corral Talciani, Hernán. "Algunas reflexiones sobre la Constitucio-

- nalización del Derecho privado”. Derecho Mayor 3 (2004): 47-63.

Corral Talciani, Hernán. "Sobre la responsabilidad civil de los peri- 
- odistas y de los medios de comunicación social por atentados a la honra, intimidad e imagen". Información Pública 4, nº 2 (2006): 253-286.

De Verda y Beamonte, José. "Los derechos fundamentales de la

- personalidad (al honor, a la intimidad y a la propia imagen) como categoría unitaria”. Revista Boliviana de Derecho 23 (2017): 54-111.

Domínguez Águila, Ramón. "Aspectos de la constitucionalización

- del Derecho civil chileno". Revista Derecho y Jurisprudencia y Gaceta de los Tribunales 93, $\mathrm{n}^{\circ} 3$ (1996): 107-137.

- Favoreu, Louis Joseph. “La Constitucionalización del Derecho”. Revista de Derecho Valdivia 12, $\mathrm{n}^{0} 1$ (2001): 31-43.

Ferrada Bórquez, Juan Carlos. La constitucionalización del Derecho

- chileno. Santiago: Editorial Jurídica de Chile-Universidad Austral de Chile, 2003.

Figueroa Yáñez, Gonzalo. "Los derechos de la personalidad en - general: concepción tradicional”. Revista de Derecho de la Pontificia Universidad Católica de Valparaíso 19, (1998): 21-34.

- Fueyo Laneri, Fernando. Instituciones de Derecho civil moderno. Santiago: Editorial Jurídica de Chile, 1990.

- Gómez Bernales, Gastón. Derechos fundamentales y recurso de protección. Santiago: Universidad Diego Portales, 2005.

Guzmán Brito, Alejandro. "La naturaleza de las garantías constitucionales de la persona examinada a través de su protección judi-

- cial". Revista de Derecho y Jurisprudencia y Gaceta de los Tribunales 85, $\mathrm{n}^{\circ} 2$ (1988): 105-112.

- Guzmán Brito, Alejandro. El Derecho Privado Constitucional de Chile. Valparaíso: Ediciones Universitarias de Valparaíso, 2001.

Guzmán Brito, Alejandro. Las cosas incorporales en la doctrina y en

- el Derecho positivo. $2^{a}$ ed. actualizada. Santiago: Editorial Jurídica de Chile, 2006.

- Herrero Tejedor, Fernando. Honor, intimidad, propia imagen. Madrid: Editorial Colex, 1990.

Hohfeld, Wesley Newcomb. Conceptos jurídicos fundamentales. $5^{\mathrm{a}}$ - reimpresión de la primera edición. Traducido por Genaro Carrió. México D.F.: Distribuciones Fontamara S.A., 2004. 
- Larraguibel Zavala, Santiago. Tratado de marcas comerciales. Santiago: Editorial Jurídica, 1987.

Larraín Páez, Cristián. "Jurisprudencia reciente en materia de responsabilidad civil por ejercicio no autorizado del derecho a la imagen. En particular, sobre el daño". Estudios de Derecho Civil VIII. Jornadas Nacionales de Derecho Civil. Santa Cruz 2012, coord.

- Carmen Domínguez Hidalgo Santiago: Legal Publishing, Thomson Reuters (2012): 573-583.

López Santa María, Jorge. "Consideraciones sobre el derecho a la - privacidad o al secreto de la vida privada”. Revista de Derecho y Jurisprudencia y Gaceta de los Tribunales, t. 79, $\mathrm{N}^{\circ} 3$ (1982): 65-78.

- Lyon Palma, Alberto. Personas naturales. $3^{\mathrm{a}}$ ed. ampliada. Santiago: Ediciones Universidad Católica de Chile, 2007.

Nino, Carlos Santiago. Introducción al análisis del Derecho. $12^{\mathrm{a}}$

- reimpresión de la $2^{\mathrm{a}}$ edición ampliada y revisada. Buenos Aires: Editorial Astrea, 2003.

Nogueira Alcalá, Humberto. "La constitucionalización del proceso: el acceso a la jurisdicción, tutela judicial efectiva o debido proceso". La constitucionalización del Derecho chileno, coord. Juan Carlos

- Ferrada Bórquez. Santiago: Editorial Jurídica de Chile-Universidad Austral de Chile (2003): 169-207.

- Nogueira Alcalá, Humberto. Derechos fundamentales y garantías constitucionales. $3^{\mathrm{a}}$ ed., Tomo I. Santiago: Librotecnia, 2010.

Nogueira Alcalá, Humberto. "El derecho a la propia imagen como

- derecho fundamental implícito. Fundamentación y caracterización”. Revista Ius et Praxis 13, nº 2 (2007): 245-285.

Nogueira Alcalá, Humberto. "El recurso de protección en el con-

- texto del amparo de los derechos fundamentales latinoamericano e interamericano". Revista Ius et Praxis 13, n 1 (2007): 75-134.

Novoa Monreal, Eduardo. Derecho a la vida privada y libertad de - información. Un conflicto de derechos. $2^{\mathrm{a}}$ ed. México: Siglo XXI Editores S.A., 1981.

Peña Atero, José Ignacio. “La protección del derecho a la propia - imagen”. Revista de Derecho Público de la Facultad de Derecho de la Universidad de Chile 64 (2002): 283-308. 
- Peñailillo Arévalo, Daniel. Los bienes, la propiedad y otros derechos reales. Reimpresión de la $1^{\mathrm{a}}$ ed. Santiago: Editorial Jurídica, 2009.

- Perla Velaochaga, Ernesto. "El derecho a la propia imagen”. Derecho PUCP, $\mathrm{n}^{\circ} 1$ (1944): 31-39.

Pfeffer Urquiaga, Emilio. "Los derechos a la intimidad o privacidad,

- a la honra y a la propia imagen. Su protección frente a la libertad de opinión e información”. Ius et Praxis 6, nº 1 (2000): 465-474.

Rogel Vide, Carlos. "Origen y actualidad de los derechos de la per-

- sonalidad". IUS: Revista del Instituto de Ciencias Jurídicas de Puebla A.C. 20 (2007): 260-282.

- Schmitt, Carl. Teoría de la Constitución. $2^{a}$ reimpresión. Traducido por Francisco Ayala. Salamanca: Alianza Editorial, 1996.

- Stitchkin Branover, David. "Los bienes extrapatrimoniales”. Revista de Derecho de la Universidad de Concepción 29, n 115 (191): 2-29.

Varas Alfonso, Paulino. "El respeto a todo derecho inherente a la

- persona, aunque no esté contemplado en el texto de la Constitución”. Revista Chilena de Derecho 20, nº 2 y 3 (1993): 725-729.

Varas, Juan Andrés. "Limitaciones a la propiedad: una perspectiva civil”. La constitucionalización del Derecho chileno, coord. Juan

- Carlos Ferrada Bórquez. Santiago: Editorial Jurídica de Chile-Universidad Austral de Chile (2003): 143-165.

Vial Solar, Tomás. "El derecho a la libertad de creación artística en la Constitución". Libertad de expresión en Chile, ed. por Felipe

- González, Santiago: Facultad de Derecho, Universidad Diego Portales (2006): 243-284.

Vidal Beros, Christian. "La protección del derecho a la propia imagen como derecho de la personalidad en un mundo globalizado". AA.VV. XXXV Jornadas de Derecho Público. El Derecho Público chileno y la globalización, Tomo I, Valparaíso: Edeval (2006): 531-539. 